\title{
LIQUID PHASE SINTERING OF DENSE AND POROUS COMPOSITES OBTAINED FROM INDUSTRIAL WASTES
}

\author{
Darko Miloševski, Ranko Adjiski, Emilija Fidančevska \\ Faculty of Technology and Metallurgy, "SS. Cyril and Methodius" University, \\ P.O. Box 580, MK-1001 Skopje, Republic of Macedonia \\ emilijaf@tmf.ukim.edu.mk
}

\begin{abstract}
Metallurgical slag and waste TV glass hawe been used for fabrication of ceramic-glass composite with a controlled porosity. A dense composite consisted of $70 \mathrm{wt} \%$ slag and $30 \mathrm{wt} \% \mathrm{TV}$ glass sintered at $1000{ }^{\circ} \mathrm{C} / 2 \mathrm{~h}$, with the integral porosity of $16 \%$, has the E-modulus and bending strength of $26.0 \pm 1.6 \mathrm{GPa}$ and $60.8 \pm 1.9 \mathrm{MPa}$, respectively. Slag with granulation of $0.125 \div 0.063 \mathrm{~mm}$ and $20 \mathrm{wt} \% \mathrm{TV}$ glass, sintered at $950{ }^{\circ} \mathrm{C} / 2 \mathrm{~h}$ possesses integral porosity of $37 \%$ and E-modulus and bending strength of $11.86 \pm 2 \mathrm{GPa}$ and $23.14 \pm 2 \mathrm{MPa}$, respectively, while the composite with the same composition but with porosity of $65 \%$ possesses E-modulus of $2.1 \pm 0.3 \mathrm{GPa}$ and bending strength of $3.0 \pm 0.4 \mathrm{MPa}$. The technical coefficient of thermal expansion of the porous systems is $11.12 \cdot 10^{-6} /{ }^{\circ} \mathrm{C}$. The porous composites have been in thermal equilibrium and acted stable in aggressive media.
\end{abstract}

Key words: metallurgical slag; waste glass; sintering; porous structure; mechanical properties; thermal expansion

\section{ТЕЧНО ФАЗНО СИНТЕРУВАЊЕ НА ГУСТИ И ПОРОЗНИ КОМПОЗИТИ ДОБИЕНИ ОД ИНДУСТРИСКИ ОТПАД}

\begin{abstract}
Металуршка троска и отпадно стакло од ТВ-екрани беа користени за добивање стакло-керамички композит со контролирана порозност. Густ композит составен од 70 мас.\% троска и 30 мас.\% ТВ стакло, синтерувано на $1000{ }^{\circ} \mathrm{C} / 2 \mathrm{~h}$, со $16 \%$ интегрална порозност има Е-модул од $26,0 \pm 1,6 \mathrm{GPa}$ и јачина на свиткување од $60,8 \pm 1,9 \mathrm{MPa}$. Троска со гранулација $0,125 \div 0,063 \mathrm{~mm}$ и 20 мас.\% ТВ стакло, синтерувано на $950{ }^{\circ} \mathrm{C} / 2 \mathrm{~h}$ даваат композит со интегрална порозност од $37 \%$, Е-модул $11,86 \pm 2 \mathrm{GPa}$ и јачина на свиткување $23,14 \pm 2 \mathrm{MPa}$, додека композит со ист состав, но со порозност од $65 \%$ има Е-модул $2,1 \pm 0,3 \mathrm{GPa}$ и јачина на свиткување $3,0 \pm 0,4 \mathrm{MPa}$. Техничкиот коефициент на термичка експанзија на порозниот систем е $11,12 \cdot 10^{-6} /{ }^{\circ} \mathrm{C}$. Порозниот композит е во термичка рамнотежа и е стабилен во агресивни средини.
\end{abstract}

Клучни зборови: металуршка троска; отпадно стакло; синтерување; порозна структура; механички особини; термичка експанзија

\section{INTRODUCTION}

In the last few decades there has been considerable research on the production of composites from silicate wastes. Silicate residues like coal power station ash, bottom ash and fly ash from waste incinerators, slag from steel production, red mud from hydrometallurgy are subjects for obtaining of this kind of composites.
Ceramics-glass as one of this kind of composites demonstrates considerable advantages over inorganic materials, such as glasses and ceramics. Usually ceramic-glass composites are not fully crystalline; typically the microstructure is $50-95$ vol $\%$ crystalline with the remainder being residual glass [1-3].

A variety of waste compositions and morphology necessitate the employment of specific proc- 
essing routes and conditions and result in ceramics-glass with a range of microstructures and properties. A few recent studies involved sintering route to produce this kind of composites [4-6].

Dense ceramic-glass materials with adequate mechanical properties have been used as substitutes of commercial building materials, like floor and wall tiles [7]. It is also especially important to use these wastes as raw materials for production of porous glass ceramics. Low density, high surface area, low thermal conductivity, and good thermal shock resistance are main characteristics of the porous materials. So, in relation to the above mentioned properties the porous materials are often used as thermal isolators, lightweight structural components, filters, heat exchangers, diffusers for water purification $[7,9,10]$ etc. Different materials have been used for production of porous structures. For instance, polyurethane foam [10], carbonates [11], carbon fibers [12], powder of carbon etc., have been used as creators of porous structures in various studies.

In the present paper the fabrication and characteristics of dense and porous composites consisted of metallurgical slag and waste glass have been investigated. The fabrication of controlled porous structure was realized using (controlled) bigger granulations of the slag particles $(0.125 \div$ $0.063) \mathrm{mm}$ interconnected with glass bridges and also the method of impregnation were applied. Glass from TV screens was used to promote liquid phase sintering at relatively lower temperatures where the ecologically risky components were molecularly fixed in the silicate phase. This investigation was realized using a multibarrier-concept proposed by Ondracek [12] and basically investigated for various waste combinations $[13,14]$.

\section{EXPERIMENTAL PROCEDURE}

Metallurgical slag from the iron factory Sartrid, Serbia and waste glass from TV monitors were used as raw materials. Chemical analysis of the raw materials was carried out by using an atomic absorption spectrophotometer (Rank Hilger, Atom Spek H-1580) and wet chemical methods. The crystalline phases of the slag were identified by X-ray diffraction (XRD) analysis (Philips PW 1130) on powdered sample, using $\mathrm{CuK}_{\alpha}$ radiation. The density of the slag and glass were determined by the picnometer method using water as the im- mersion liquid. Thermal characteristics were determined by a heating microscope (Leitz) in the temperature interval $\mathrm{RT}-1400{ }^{\circ} \mathrm{C}$ with a heating rate of $10{ }^{\circ} \mathrm{C} / \mathrm{min}$. The morphology of the wastes used and the microstructures of the porous composites obtained were made using a scanning electron microscope (SEM Leica S 440i).

To obtain the dense composites, the raw materials were ground in a ball mill and screened through a $45 \mu \mathrm{m}$ screen. Glass from TV monitors (only from the screen) was treated with $10 \% \mathrm{HF}$ and $\mathrm{NH}_{4} \mathrm{~F}$ in order to dissolve all non glassy elements [8]. The content of the glass in the dense composite was 10, 20, 30, 40 and $50 \mathrm{wt} \%$.

Homogenization of the mineral waste (slag) and glass was performed in a planetary mill (Fritsch pulverisette). Pressing of the samples was performed by a uniaxial press (Weber Pressen KIP 100). A pressure of $50 \mathrm{MPa}$ was employed to reach green densities of $43 \%$ of the theoretical density. Sintering was realized in the chamber furnace in air atmosphere in a temperature region from 850 to $1200{ }^{\circ} \mathrm{C}$, using a heating rate of 10 ${ }^{\circ} \mathrm{Cmin}^{-1}$ and isothermal treatment at the final temperature of $2 \mathrm{~h}$. Bulk density of the sintered samples was determined by the water displacement method. The value of theoretical density of compacts was calculated based on composition of the initial mixture and known density of slag and glass. This is not accurate theoretical as it does not take into account any change in phases and their proportions that occur during sintering; it is however sufficient for comparison purposes with relatively porous products. Mechanical properties (Emodulus and bending strength) of the dense and porous specimens $\left(8\right.$ pieces, $\left.50 \times 5 \times 5 \mathrm{~mm}^{3}\right)$ were investigated at room temperature. The samples were subjected to the 3-point bending tester (Netzsch 401/3) with $40 \mathrm{~mm}$ span and $0.5 \mathrm{~mm} / \mathrm{min}$ crosshead speed. Linear thermal expansion of the sintered samples was determined with a dilatometer (Netzsch 402E) at air atmosphere in the temperature interval RT-650 ${ }^{\circ} \mathrm{C}-\mathrm{RT}$. The measurements were performed with a heating rate of 2 ${ }^{\circ} \mathrm{C} / \mathrm{min}$. Composites with a controlled porosity were prepared by powder technology.

Porous samples were made of slag and TV glass, varying the slag particle size as $0.500 \div 0.250$ $\mathrm{mm}, 0.250 \div 0.125 \mathrm{~mm}, 0.125 \div 0.063 \mathrm{~mm}$ and 0.063 $\div 0.045 \mathrm{~mm}$; the TV glass particle size was kept constant and lower than $0.045 \mathrm{~mm}$. The slag and TV glass powders were mechanically mixed in a 
rotary mixer for 2 hours. The glass content was 10 , 20, 30 and $40 \mathrm{wt} \%$. Green bars $\left(60 \times 5 \times 5 \mathrm{~mm}^{3}\right)$ were uniaxially pressed (Weber Presen KIP 100), using a pressure of $22 \mathrm{MPa}$, and polyvinyl alcohol was used as a binder. Greens were sintered in an electrical furnace in air atmosphere with a heating rate of $5{ }^{\circ} \mathrm{C} / \mathrm{min}$. The sintering temperature was $850,900,950$ and $1000{ }^{\circ} \mathrm{C}$ and the soaking time at the final temperature was 2 hours. Density of the sintered samples was determined from the ratio of mass and volume.

Another way for fabrication of open celled composites was by coating the struts of polyurethane foam with a ceramic-glass slurry (method of impregnation) and then firing the resultant structure to pyrolyse the substrate and sintering the ceramic system [17]. The particle size of the slag and glass was less than $45 \mu \mathrm{m}$. The content of the glass in the composite was $20 \mathrm{wt} \%$. Commercial polyurethane foam with density of $25 \mathrm{~kg} / \mathrm{m}^{3}$ was used as a substrate. The slurry contained $58 \%$ solid, $15 \%$ defloculant (Dolapix CE 64) and the rest distilled water. It coherently coated the polyurethane substrates. The foam was squeezed and dipped into slurry, looking in that case like a sponge. During the expansion to the original shape and size, the foam was impregnated by the mentioned slurry. After drying, the coated substrates were heated up to $950{ }^{\circ} \mathrm{C}$ in a schedule which minimized disruption during pyrolysis and allowed the ceramic to achieve high density. This heating schedule consisted of a heating rate of $0.5^{\circ} \mathrm{C} / \mathrm{min}$ up to $800{ }^{\circ} \mathrm{C}$ and rapid heating of $10{ }^{\circ} \mathrm{C} / \mathrm{min}$ from 800 to $950{ }^{\circ} \mathrm{C}$, $2 \mathrm{~h}$ held at $950{ }^{\circ} \mathrm{C}$ and then cooling in the furnace.

The leaching behavior of the composites was tested using standard methods both for glasses and ceramics. The durability was determined as a mass lost in $0.1 \mathrm{~mol} / \mathrm{dm}^{3} \mathrm{HCl}$ and $0.1 \mathrm{~mol} / \mathrm{dm}^{3} \mathrm{Na}_{2} \mathrm{CO}_{3}$ in the period of 30 days.

\section{RESULTS AND DISCUSSION}

The chemical compositions of the wastes used are shown in Table 1.

Metallurgical slag refers to the multicomponent silicate system. Following the XRD analysis, the slag showed the presence of Akermanite $\left(\mathrm{Ca}_{2} \mathrm{MgSi}_{2} \mathrm{O}_{7}\right)$, Merwinite $\left(\mathrm{Ca}_{3} \mathrm{MgSi}_{2} \mathrm{O}_{8}\right)$, and glassy phase.

The morphology of the milled slag and glass powders with particle size less than $45 \mu \mathrm{m}$ are shown in Fig. 1 and Fig. 2.
Table 1

Chemical composition of the metallurgical slag SARTRID and waste TV glass

\begin{tabular}{lcc}
\hline \hline Oxide & Slag, $\mathrm{wt} \%$ & TV glass, $\mathrm{wt} \% \mathrm{wt} \%$ \\
\hline $\mathrm{SiO}_{2}$ & 39.91 & 58.80 \\
$\mathrm{TiO}_{2}$ & $/$ & 0.09 \\
$\mathrm{Al}_{2} \mathrm{O}_{3}$ & 7.42 & 3.55 \\
$\mathrm{Cr}_{2} \mathrm{O}_{3}$ & 0.01 & $/$ \\
$\mathrm{Fe}_{2} \mathrm{O}_{3}$ & 0.41 & 0.31 \\
$\mathrm{CaO}$ & 39.93 & 1.61 \\
$\mathrm{MgO}$ & 7.88 & 2.42 \\
$\mathrm{Na} \mathrm{O}_{2} \mathrm{O}$ & 0.95 & 7.10 \\
$\mathrm{~K}_{2} \mathrm{O}$ & 0.72 & 6.10 \\
$\mathrm{PbO}$ & $/$ & 8.18 \\
$\mathrm{BaO}$ & $/$ & 4.81 \\
$\mathrm{CoO}$ & $/$ & 0.08 \\
$\mathrm{SrO}$ & $/$ & 0.08 \\
$\mathrm{ZnO}$ & $/$ & 0.06 \\
$\mathrm{SO} \mathrm{O}_{3}$ & 1.50 & 0.11 \\
$\mathrm{CO}$ & 0.38 & 6.30 \\
\hline$\Sigma$ & 99.11 & 99.60 \\
\hline \hline
\end{tabular}

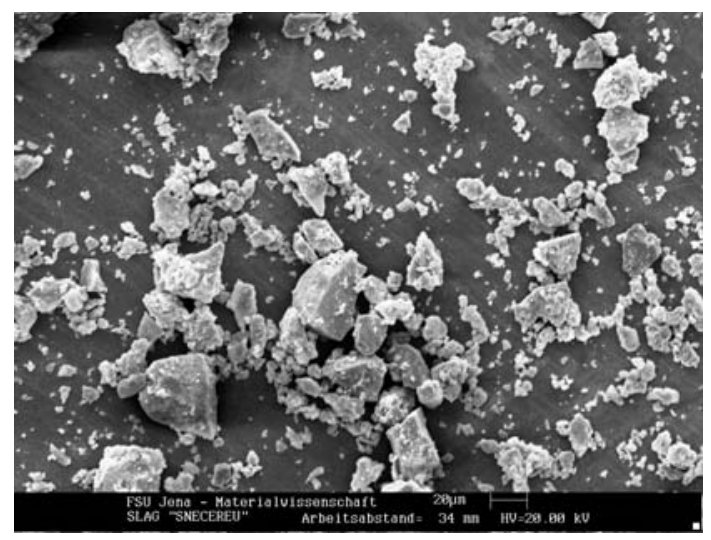

Fig. 1. SEM micrograph of the milled slag powder (bar $20 \mu \mathrm{m}$ )

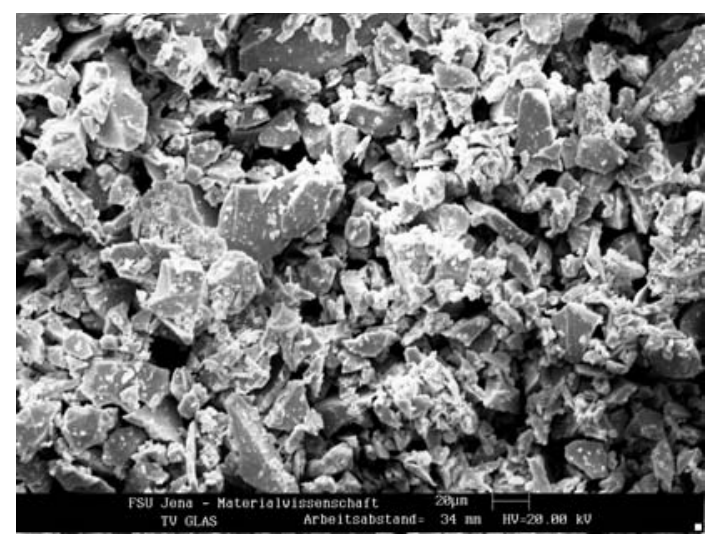

Fig. 2. SEM micrograph of the milled glass powder (bar $20 \mu \mathrm{m}$ ) 
As it can be seen from Fig. 1 and Fig. 2, the slag and TV glass particles have irregular geometry and shape edges, with sizes ranging from 5 to $45 \mu \mathrm{m}$. The densities of the slag and glass are 2.84 $\mathrm{g} / \mathrm{cm}^{3}$ and $2.61 \mathrm{~g} / \mathrm{cm}^{3}$, respectively.

Thermal characteristics of the slag and TV glass are given in Table 2 .

Table 2

\section{Thermal characteristics of the slag and waste glass $\left({ }^{\circ} \mathrm{C}\right)$}

\begin{tabular}{lccc}
\hline Material & $\begin{array}{c}\text { Significant } \\
\text { shrinkage }\end{array}$ & $\begin{array}{c}\text { Softening } \\
\text { temperature }\end{array}$ & $\begin{array}{c}\text { Melting } \\
\text { temperature }\end{array}$ \\
\hline Slag & 1078 & 1265 & 1306 \\
TV glass & 605 & 709 & 804 \\
\hline
\end{tabular}

TV glass has a relatively low melting point, due to the high content of $\mathrm{PbO}$, Table 1 .

Taking into account the results from dilatometry and high temperature microscopy, the sintering studies of the slag were carried out in the temperature range of $850-1200{ }^{\circ} \mathrm{C} / 2 \mathrm{~h}$.

E-modulus, flexural strength and porosity of the sintered slag are shown in Table 3.

Table 3

Porosity ( $\theta)$, E-modulus (E) and bending strength $(\sigma)$ of the slag sintered at different temperatures

\begin{tabular}{clll}
\hline \hline Temperature $\left[{ }^{\circ} \mathrm{C}\right]$ & $\theta[\%]$ & $E[\mathrm{GPa}]$ & $\sigma[\mathrm{MPa}]$ \\
\hline 850 & 35.9 & $4.5 \pm 0.3$ & $5.6 \pm 0.4$ \\
900 & 35.5 & $5.7 \pm 0.5$ & $7.3 \pm 0.6$ \\
950 & 34.9 & $6.4 \pm 0.5$ & $2.8 \pm 0.5$ \\
1000 & 34.1 & $7.8 \pm 0.6$ & $9.6 \pm 0.6$ \\
1100 & 33.1 & $8.6 \pm 0.5$ & $10.4 \pm 0.6$ \\
1150 & 32.4 & $11.5 \pm 1,0$ & $16.3 \pm 3.2$ \\
1200 & 32.0 & $11.7 \pm 1.5$ & $16.5 \pm 2.1$ \\
\hline \hline
\end{tabular}

Metallurgical slag reached the highest relative density of $68 \%$ or porosity of $32 \%$ after sintering at $1200{ }^{\circ} \mathrm{C} / 2 \mathrm{~h}$. E-modulus and bending strength of this system were $11.7 \pm 1.5 \mathrm{GPa}$ and $16.5 \pm 2.1$ $\mathrm{MPa}$, respectively. Sintering at a higher temperature of $1200{ }^{\circ} \mathrm{C}$ exhibited side effects such as bending.

With the purpose of aiding the sintering process and encapsulating the particles of the slag into a matrix compatible with the environment, waste TV glass in quantity of $10,20,30,40$ and $50 \% \mathrm{wt}$. has been used. Technical coefficients of thermal expansion of slag and TV glass were $11.26 \cdot 10^{-6} /{ }^{\circ} \mathrm{C}$ and $10.61 \cdot 10^{-6} /{ }^{\circ} \mathrm{C}$, respectively, while E-modulus of slag (32\% porosity) and glass were 11.7 and 72 $\mathrm{GPa}$, respectively. These two parameters are needed for keeping the low level of internal stresses in the composite after fabrication at high temperature [19].

The sintering regime of the designed slagglass compacts was $850-1000{ }^{\circ} \mathrm{C} / 2 \mathrm{~h}$. The presence of liquid phase as a result of addition of TV glass significantly reduced the region of sintering, while simultaneously increased the mechanical properties of sintered composites.

E-modulus, bending strength, and porosity in function of sintering temperature of the investigated composites are shown in Table 4.

Table 4

Porosity ( $\theta)$, E-modulus (E) and bending strength $(\sigma)$ of the composites sintered at different temperatures

\begin{tabular}{lcccc}
\hline \hline Composite & $t\left[{ }^{\circ} \mathrm{C}\right]$ & $\theta[\%]$ & $E[\mathrm{GPa}]$ & $\sigma[\mathrm{MPa}]$ \\
\hline [\% TV glass $]$ & & & & \\
\hline Slag +10 & 850 & $27.7 \pm 0.6$ & $17.1 \pm 0.8$ & $34.1 \pm 0.8$ \\
Slag +10 & 900 & $27.9 \pm 0.8$ & $17.8 \pm 0.6$ & $34.6 \pm 1.1$ \\
Slag +10 & 950 & $26.1 \pm 0.7$ & $18.6 \pm 0.8$ & $35.0 \pm 1.0$ \\
Slag +100 & 1000 & $25.6 \pm 0.6$ & $19.5 \pm 1.0$ & $35.3 \pm 1.0$ \\
\hline Slag +20 & 850 & $19.6 \pm 0.8$ & $20.1 \pm 0.8$ & $36.5 \pm 1.0$ \\
Slag +20 & 900 & $18.9 \pm 0.8$ & $21.6 \pm 0.8$ & $37.0 \pm 1.0$ \\
Slag +20 & 950 & $17.6 \pm 1.0$ & $22.5 \pm 0.7$ & $38.9 \pm 1.4$ \\
Slag +20 & 1000 & $17.0 \pm 0.8$ & $23.3 \pm 0.8$ & $40.1 \pm 1.3$ \\
\hline Slag +30 & 850 & $17.1 \pm 1.6$ & $23.8 \pm 1.2$ & $40.7 \pm 1.1$ \\
Slag +30 & 900 & $16.3 \pm 1.9$ & $24.6 \pm 1.0$ & $59.4 \pm 1.7$ \\
Slag +30 & 950 & $16.0 \pm 0.5$ & $25.1 \pm 0.7$ & $59.8 \pm 2.0$ \\
Slag +30 & 1000 & $15.7 \pm 0.9$ & $26.0 \pm 1.6$ & $60.8 \pm 1.9$ \\
\hline Slag +40 & 850 & $16.5 \pm 0.9$ & $24.9 \pm 1.0$ & $59.1 \pm 2.0$ \\
Slag +40 & 900 & $16.0 \pm 1.0$ & $25.1 \pm 1.5$ & $60.2 \pm 1.4$ \\
Slag +40 & 950 & $15.8 \pm 0.5$ & $25.1 \pm 1.2$ & $60.5 \pm 1.9$ \\
Slag +40 & 1000 & $15.3 \pm 1.1$ & $26.0 \pm 1.8$ & $61.0 \pm 1.6$ \\
\hline Slag +50 & 850 & $15.9 \pm 0.6$ & $25.4 \pm 1.8$ & $60.6 \pm 2.0$ \\
Slag +50 & 900 & $15.9 \pm 0.9$ & $25.4 \pm 1.7$ & $60.4 \pm 1.9$ \\
Slag +50 & 950 & $15.9 \pm 0.5$ & $25.4 \pm 1.7$ & $60.7 \pm 2.1$ \\
Slag +50 & 1000 & $15.8 \pm 0.4$ & $25.4 \pm 1.7$ & $60.4 \pm 1.9$ \\
\hline \hline
\end{tabular}


Taking into account porosity, E-modulus and bending strength of the sintered composites as the selection criteria, the composites composed of slag $+30 \mathrm{wt} \%$ TV glass, sintered at $1000{ }^{\circ} \mathrm{C}$ have optimal properties, Table 4.

As it can be seen from Table 4, by increasing the temperature and glass content, the porosity of the composite decreased while the E-modulus and the bending strength increased.

Comparing the data from Table 3 and Table 4 , it is evident that the glass addition increases the mechanical properties of the composites for several times.

The thermal expansion characteristics of the composite slag $+30 \mathrm{wt} \%$ glass in the interval RT650-RT, showed the absence of the hysteresis effect, which proves that the system is in thermal equilibrium. The fabricated composites possessed thermal stability, which means there was no appearance of fractures.

The temperature dependence of the thermal expansion in the interval $\mathrm{RT}-650^{\circ} \mathrm{C}$ can be presented by an III order polynomial form:

$$
\Delta \mathrm{L} / \mathrm{L}=-0.342+0.022 \mathrm{~T}-3.782 \cdot 10^{-5} \mathrm{~T}^{2}+4.929 \cdot 10^{-8} \mathrm{~T}^{3}
$$

Differentiating the above expression, the temperature dependence of the physical coefficient of thermal expansion could be derived:

$$
\partial(\Delta \mathrm{L} / \mathrm{L}) / \partial \mathrm{T}=0.022-7.564 \cdot 10^{-5} \mathrm{~T}+9.858 \cdot 10^{-8} \mathrm{~T}^{2}
$$

The technical coefficient of thermal expansion in the range $\mathrm{RT}-650^{\circ} \mathrm{C}$ was $11.04 \cdot 10^{-6} /{ }^{\circ} \mathrm{C}$.

In order to fabricate the porous composite slag-TV glass, the following articles of slag were used: $0.500 \div 0.250 \mathrm{~mm}, 0.250 \div 0.125 \mathrm{~mm}, 0.125 \div$ $0.063 \mathrm{~mm}$ and $0.063 \div 0.045 \mathrm{~mm}$ ); the TV glass particle size was kept constant and lower than $45 \mu \mathrm{m}$. The content of the glass was 10, 20, 30 and $40 \mathrm{wt} \%$.

According to our investigations $[10,16,17]$ up to now it has been shown that the optimal temperature/time of sintering for this type of porous composites was $950{ }^{\circ} \mathrm{C} / 2 \mathrm{~h}$. At this temperature/time, the viscosity of the melt glass is so, that it covers coherently the matrix. Among the particles being covered with melt glass it is formed liquid bridges enabling the liquid-phase sintering.

Using the porosity, E-modulus and bending strength as a criterion of selection, have shown that the composite slag $0.125 \div 0.063 \mathrm{~mm})+20 \mathrm{wt} \% \mathrm{TV}$ glass possesses optimal properties. The composite was characterized with relative density of approximately $63.0 \pm 2 \%$ from the theoretical one, and E-modulus and bending strength of $11.86 \pm 2$ $\mathrm{GPa}$ and $23.14 \pm 2 \mathrm{MPa}$, respectively.

SEM micrographs of this porous composite are shown in Fig. 3 and Fig. 4.

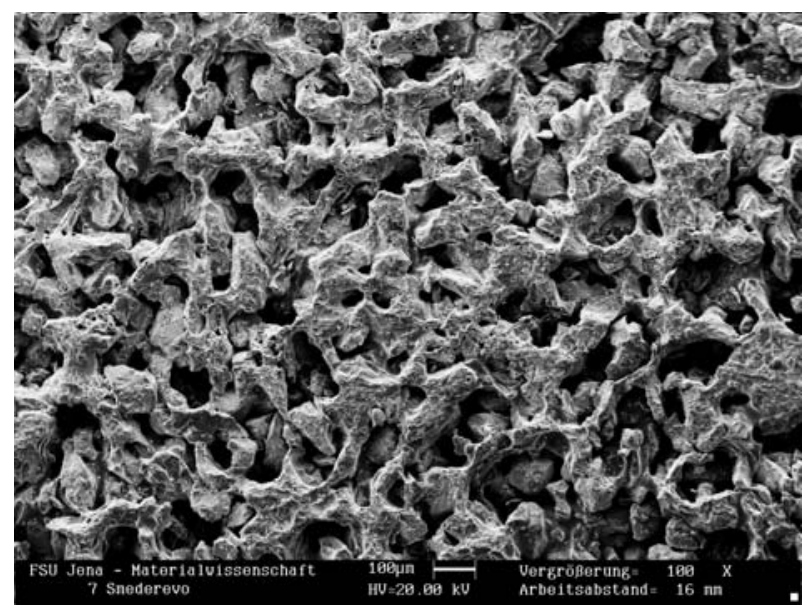

Fig. 3. Microstructure of the porous composite slag $(0.125 \div 0.063 \mathrm{~mm})+20 \mathrm{wt} \% \mathrm{TV}$ glass sintered at $950^{\circ} \mathrm{C} / 2 \mathrm{~h}$ (bar $100 \mu \mathrm{m})$

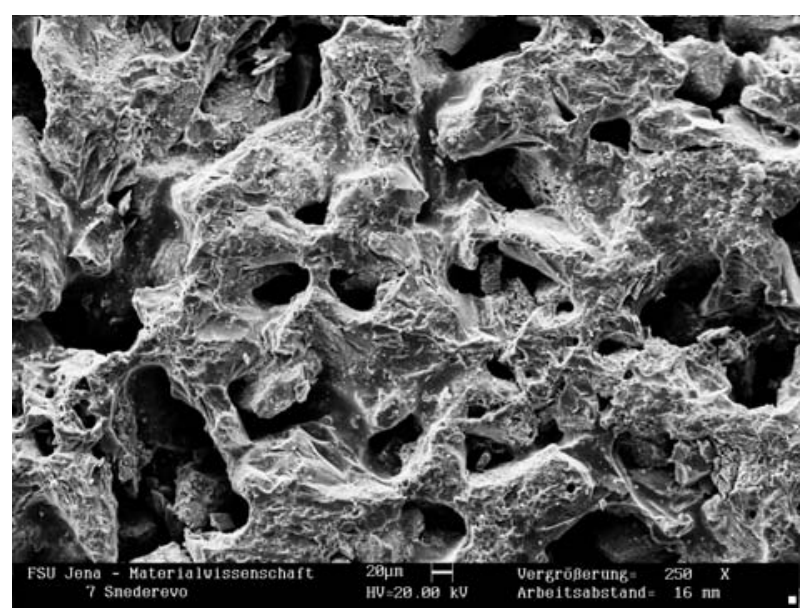

Fig. 4. Microstructure of the porous composite slag $(0.125 \div 0.063 \mathrm{~mm})+20 \mathrm{wt} \% \mathrm{TV}$ glass sintered at $950{ }^{\circ} \mathrm{C} / 2 \mathrm{~h}$ (bar $20 \mu \mathrm{m}$ )

The pores are interconnected with sizes of 20-200 $\mu \mathrm{m}$. Fractures among the pore walls were not evident. The slag grains are surrounded by the glassy phase, allowing in that way to stop or decrease the dissolving process of the ecologically risky elements consisted in the waste. Glass bridges are formed between the slag particles dur- 
ing sintering, giving the mechanical strength of the sintered composite.

Using of polyurethane foam as a creator of porous structure, samples with porosity of $65 \pm 5 \%$ were fabricated, Fig.5. The pores with a diameter from $1000-5000 \mu \mathrm{m}$ were mainly interconnected. The E-modulus and bending strength of this system are $2.1 \pm 0.3 \mathrm{GPa}$ and $3.0 \pm 0.4 \mathrm{MPa}$, respectively. After pyrolysis of the foam, no residue was considered.

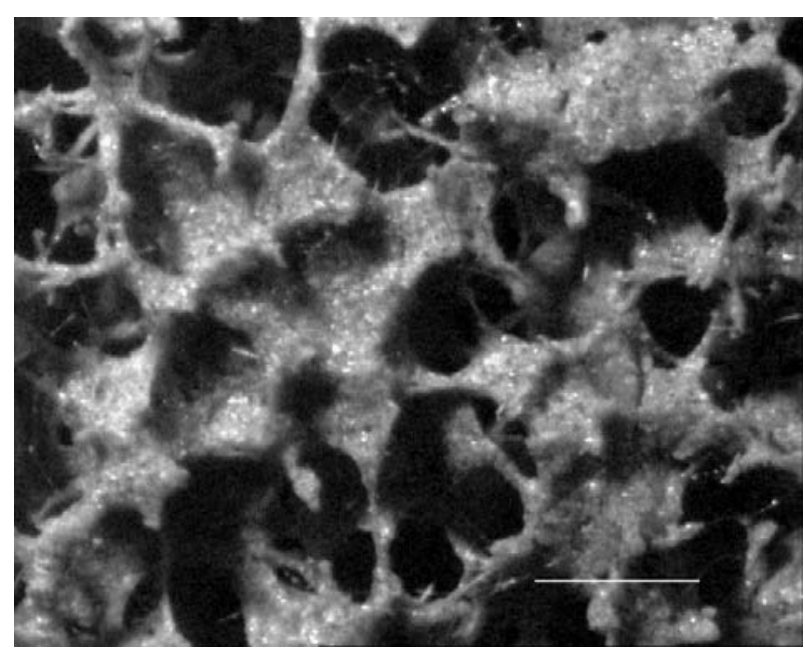

Fig.5. Macrostructure of cell foam, using polyurethane foam as pores creator (bar $5 \mathrm{~mm}$ )

Thermal expansion investigations of the porous composite slag of $0.125 \div 0,063 \mathrm{~mm}+20 \mathrm{wt} \%$ TV glass, showed the absence of the effect of hysteresis in the heating/cooling region $\mathrm{RT}-650^{\circ} \mathrm{C}-$ $\mathrm{RT}$, proving that this system is in thermal equilibrium. The temperature dependence of thermal expansion, represented as a III order polynomial form is given, in equation 3 :

$$
\Delta \mathrm{L} / \mathrm{L}=-0.185+0.011 \mathrm{~T}-8.549 \cdot 10^{-6} \mathrm{~T}^{2}+1.127 \cdot 10^{-8} \mathrm{~T}^{3}
$$

By differentiation of this polynomial, the temperature dependence of the physical coefficient of thermal expansion $\partial(\Delta \mathrm{L} / \mathrm{L}) / \partial \mathrm{T}$, is delivered:

$$
\partial(\Delta \mathrm{L} / \mathrm{L}) / \partial \mathrm{T}=0.011-17.09 \cdot 10^{-6} \mathrm{~T}+4.236 \cdot 10^{-8} \mathrm{~T}^{2}
$$

The technical coefficient of thermal expansion was $11.12 \cdot 10^{-6} /{ }^{\circ} \mathrm{C}$.

The durability values (mass lost after 30 days) of the designed porous systems of $0.125 \div 0.063 \mathrm{~mm}$ +20 wt. $\%$ TV glass was $1.32 \%$ in $0.1 \mathrm{~mol} / \mathrm{dm}^{3}$
$\mathrm{HCl}$ and $0.002 \%$ in $0.1 \mathrm{~mol} / \mathrm{dm}^{3} \mathrm{Na}_{2} \mathrm{CO}_{3}$. The atomic absorption spectroscopy did not show the presence of any harmful elements in the obtained solution. The durability values allowed the categorization of this material, for the purpose of defining classes according to DIN EN 122. The composite slag of $0.125 \div 0.063 \mathrm{~mm}+20 \mathrm{wt} \% \mathrm{TV}$ glass, could be characterized as the class B (visible change in colour). This porous composite is potential material for producing diffusers which could be used for water aeration.

\section{CONCLUSION}

A dense composite consisted of $70 \mathrm{wt} \%$ slag and $30 \mathrm{wt} \% \mathrm{TV}$ glass sintered at $1000^{\circ} \mathrm{C} / 2 \mathrm{~h}$, possesses integral porosity of $16 \%$, E-modulus and bending strength of $26.0 \pm 1.6 \mathrm{GPa}$ and $60.8 \pm$ 1.9 MPa, respectively.

Ecologically harmless glass ceramics with controlled porosity could be created from slag with granulation $0.125 \div 0.063 \mathrm{~mm}$ activated with 20 wt $\%$ waste TV glass.

The composite sintered at $950{ }^{\circ} \mathrm{C} / 2 \mathrm{~h}$ possesses total porosity of $37.0 \pm 2 \%$, and mechanical properties such as E-modulus and bending strength of $11.86 \pm 2 \mathrm{GPa}$ and $23.14 \pm 2 \mathrm{MPa}$, respectively.

The obtained glass ceramic composite is in thermal equilibrium in the temperature interval of $20-650{ }^{\circ} \mathrm{C}$.

Technical coefficient of thermal expansion of the porous composites is $11.12 \cdot 10^{-6} /{ }^{\circ} \mathrm{C}$.

The obtained porous composite acted stable (mass lost after 30 days) in aggressive media, where a relative mass loss of $1.32 \mathrm{wt} \%$ was evidenced after treatment in $0.1 \mathrm{~mol} / \mathrm{dm}^{3} \mathrm{HCl}$ for 30 days.

The porous composite is potential material for producing diffusers which could be used for water aeration.

\section{REFERENCES}

[1] R. D. Rawlings, J. P. Wu, A. R. Boccaccini, Glassceramics: Their production from waste - A review, J. Mater. Sci., 41, 733-761 (2006).

[2] W. Holland, G. Beall, Glass-ceramic Technology, The American Ceramic Society, Westerville, OH, 2002.

[3] Z. Strand, Glass-Ceramic Materials, Elsevier, Amsterdam, 1986. 
[4] H. S. Kim, R. D. Rawlings, P. S. Rogers, Sintering and crystallization phenomena in Silceram glass, J. Mater. Sci., 24, 1025-1037 (1989).

[5] R. Chimdins, I. Rozenstrauha, L. Berizina, J. Bossert, M. Bucker, Glassceramics obtained from industrial waste, Resourses, Conservation and Recycling, 29, 285-290 (2000).

[6] E. Fidancevska, V. Vassilev, M. Milosevski, S. Parvanov, D. Milosevski, L. Aljihmani, Composites on the base of industrial wastes, I. Physico-chemical properties of $\mathrm{Fe}-\mathrm{Ni}$ slag, Journal of the University of Chemical Technology and Metallurgy, 41 (4), 431-438 (2006).

[7] J. P. Wu, A. R. Boccaccini, P. D. Lee, M. J. Kershaw, R. D. Rawlings, Glass ceramic foams from coal ash and waste glass production and characterization, Adv. Appl. Ceram., 105 (1), 32-39 (2006).

[8] M. Sittig, Metal and Inorganic Waste Reclaiming Encyclopedia, Noves data corporation, New Jersey, 1980, pp. 175.

[9] E. Sousa, C. B. Silveira, T. Fey, P. Greil, D. Hotza, A. P. N. de Oliveira, LZS, A glass ceramic foams prepared by replication process, Adv. Appl. Ceram., 104, 22-29 (2005).

[10] E. Fidancevska, B. Mangutova, D. Milosevski, M. Milosevski, J. Bossert, Obtaining of dense and highly porous ceramic materials from metallurgical slag, Sci. Sinter., 35, 85-91 (2003).

[11] T. Y. Lim, Y. M. Park, J. H. Hwang, C. Y. Kim, C. Y. Kim, Fabrication and characterization of porous ceramic panel using recycled glass powder, Mater. Sci. Forum, 511, 642-645 (2000).
[12] G. Ondracek, Breg- und Huttenmannische, Monatshefte, 139, 273-279 (1994)

[13] L. Berzina, R. Cimdins, I. Rozenstrauha, J. Bossert, I. Kravchenko, Glass- Ceramics with multibarrier structure obtained from industrial waste, Key Eng. Mater., 222, 132-136 (1997).

[14] I. Kravtchenko, V. Gorobinskay, J. Bossert, Recycling of electronic glass waste, Mater. Eng., 10 (9), 193-210 (1999).

[15] A. I. Rozenstrauha, D. Bajare, R. Cimdins, L. Berzina, J. Bossert, A. R. Boccaccini, The influence of various additions on a glass-ceramic matrix composition based on industrial waste, Ceram. Int., 32, 115-119 (2006).

[16] B. Mangutova, E. Fidancevska, M. Milosevski, J. Bossert, Production of highly porous glass-ceramics from metallurgical slag, fly-ash and waste glass, $A P T E F F, 35$ (1), 103-109 (2004)

[17] R. Adziski, E. Fidancevska, B. Anguseva, D. Milosevski, V. Vassilev, M. Milosevski, Industrial waste as source for fabrication of composite ceramic glass with controled porosity, Sci. Sint., 40, 89-96 (2008).

[18] M. Milosevski, J. Bossert, D. Milosevski, N. Gruevska, Preparation and properties of dense and porous calcium phosphate, Ceram. Int., 25, 693-696 (1999).

[19] T. J. Reinhard, Engineered Materials Handbook. Composites, Vol. 1, ASM International, Metals Park, Ohio, 1987. 